\title{
Allogeneic hematopoietic cell transplantation (allo-HCT) outcomes in myeloma patients on renal replacement therapy: a report from the Chronic Malignancy Working Party (CMWP) of the European Society of Blood and Marrow Transplantation (EBMT)
}

\author{
Meral Beksac $\mathbb{D}^{1} \cdot$ Nicolaus Kröger ${ }^{2} \cdot$ Jennifer L. Byrne ${ }^{3} \cdot$ Arnold Ganser $^{4} \cdot$ Zeynep Arzu Yeğin $^{5} \cdot$ Stefan Schönland $^{6}$
}

Received: 16 June 2020 / Revised: 2 July 2020 / Accepted: 21 July 2020 / Published online: 2 August 2020

(c) Springer Nature Limited 2020

Renal impairment is present in $20 \%$ of MM patients at diagnosis. Though rapid effective treatment may prevent progression to irreversible kidney injury, $1-5 \%$ of patients still ultimately require renal replacement therapy (RRT) $[1,2]$. The median survival for myeloma patients with endstage renal disease (ESRD) have been reported to be 18.3 months [3]. In addition to adverse FISH cytogenetic markers, renal impairment is therefore still a poor prognostic feature.

In 2018, 12,758 auto-HCT and 384 allo-HCTs were performed for the treatment of plasma cell disorders [4]. Although there is evidence of a graft-versus-myeloma effect, alloHCT in MM is associated with high transplantrelated mortality (TRM) rates and is usually reserved for young patients with high-risk features [5]. Though the use of reduced intensity (RI) and non-myeloablative (NMA) conditioning chemotherapy is standard, the optimal approach for patients on RRT remains unclear $[6,7]$.

Meral Beksac

Meral.Beksac@medicine.ankara.edu.tr

1 Department of Hematology, Ankara University School of Medicine, Ankara, Turkey

2 Department for Stem Cell Transplantation, University Medical Center Hamburg-Eppendorf, Hamburg, Germany

3 Faculty of Medicine and Health Sciences, University of Nottingham, Nottingham, UK

4 Medical Faculty, University Hospital Düsseldorf/Heinrich Heine University, Düsseldorf, Germany

5 Department of Hematology, Gazi University School of Medicine, Ankara, Turkey

6 Hematology, Oncology and Rheumatology, Medical Department V, University Hospital of Heidelberg, Heidelberg, Germany
We are only aware of one report from the Fred Hutchinson Cancer Research Center presenting the outcomes of six patients on RRT who received RIC/NMA allo-HSCT between 1997 and 2014 [8]. Three of the six patients had MM and received tandem Auto-AlloHCT. Two were matched related donor transplants (one $\mathrm{BM}$, one $\mathrm{PB}$ ) who were conditioned with 2 Gy TBI followed by GvHD prophylaxis with Ciclosporin and Mycophenolate Mofetil (CSA/MMF). The first patient died of relapse at 10 months and the second of CMV pneumonitis at 11 months. The third patient received a haploidentical BM graft following Fludarabine (50\% dose), post HCT Cyclophosphamide (day 3, 75\% dose) and 2 Gy TBI. Immunosuppression consisted of MMF and Tacrolimus. This patient was alive 2 years posttransplant. The authors drew attention to the need for registries to report on such patients in order to address the feasibility and safety of allo-HSCT in ESRD patients requiring dialysis.

We sought information from EBMT centers on patients meeting the following eligibility criteria: diagnosis of $\mathrm{MM}$, age $>18$ years at time of first allogeneic transplant and dialysis dependence at time of first allogeneic transplant. Four centers reported a total of six patients. As summarized in Table 1, the patients were transplanted between 2003 and 2016. The median age was higher ( 52 vs. 45 years) than those in the report by Sharma et al. All had presented with renal impairment at diagnosis. Three (50\%) had high-risk FISH profiles (two $17 \mathrm{p}$ del, one $t(14 ; 16)$ ). All six received an upfront auto-HCT after which three proceeded directly to an allo-HCT in a tandem approach; the other three had alloHCT following relapses. All received peripheral blood stem cell products. Two received myeloablative conditioning and four received RI regimens. GvHD prophylaxis was standard (CSA/MMF) in addition to ATG or Campath. Although neutrophil engraftment was unremarkable, two patients failed to achieve platelet engraftment $(>50,000 / \mu \mathrm{L})$, this 
Table 1 Characteristics and outcomes of the six myeloma patients within the EBMT registry who were transplanted with stem cells from allogeneic donors while on hemodialysis.

\begin{tabular}{|c|c|c|c|c|c|c|}
\hline Patient & \#1 & $\# 2$ & \#3 & \#4 & $\# 5$ & \#6 \\
\hline Sex & Male & Female & Female & & & \\
\hline Age at allo-HCT & 58.40 & 39.87 & 36.05 & 57.55 & 52.03 & 52.65 \\
\hline Ig type & Light chain & $\operatorname{IgG}$ & Light chain & $\mathrm{IgG}$ & $\operatorname{IgG}$ & $\mathrm{IgG}$ \\
\hline MM stage at diagnosis & IIIB & IIIB & IIIB & IIB & IIIA & IIIB \\
\hline Cytogenetics abnormality & Not done & trisomy 9 & $\operatorname{del}(13), t(14 ; 16)$ & $\operatorname{del}(17)(\mathrm{p} 13)$ & Normal & $\operatorname{del}(17)(\mathrm{p} 13)$ \\
\hline $\begin{array}{l}\text { Dialysis dependent at } \\
\text { diagnosis }\end{array}$ & Yes & Yes & Yes & Yes & Yes & No \\
\hline Dialysis dependent at allo & Yes & Yes & Yes & Yes & Yes & Yes \\
\hline $\begin{array}{l}\text { Interval auto to allo } \\
\text { (months) }\end{array}$ & 6.39 & 3.13 & 4.25 & 35.23 & 3.89 & 7.08 \\
\hline Donor type & $\begin{array}{l}\text { Identical } \\
\text { sibling }\end{array}$ & Identical sibling & $\begin{array}{l}\text { Matched } \\
\text { unrelated }\end{array}$ & Matched unrelated & Identical sibling & $\begin{array}{l}\text { Matched } \\
\text { unrelated }\end{array}$ \\
\hline Conditioning regimen & $\begin{array}{l}\text { RIC: Flu }+ \\
\text { Mel }\end{array}$ & RIC: Flu + Mel & $\begin{array}{l}\text { RIC: Flu + Mel } \\
+ \text { ATG }\end{array}$ & $\begin{array}{l}\text { MAC: } \mathrm{Bu}+\mathrm{Cy}+ \\
\text { ATG }+ \text { TBI }(9 \mathrm{~Gy})\end{array}$ & $\begin{array}{l}\text { RIC: Flu + Mel } \\
\text { + Campath }\end{array}$ & $\begin{array}{l}\text { MAC: } \mathrm{Bu}+ \\
\text { Thiotepa }\end{array}$ \\
\hline Prophylaxis regimen & $\mathrm{CsA}+\mathrm{MMF}$ & $\mathrm{CsA}+\mathrm{MMF}$ & $\mathrm{CsA}+\mathrm{MMF}$ & $\mathrm{CsA}+\mathrm{MMF}$ & CsA alone & $\mathrm{Cy}+\mathrm{CsA}$ \\
\hline $\begin{array}{l}\text { Disease status at allo- } \\
\text { HCT }\end{array}$ & $\mathrm{CR}$ & VGPR & PR1 & Progression & Stable disease & PR1 \\
\hline $\begin{array}{l}\text { Best response of allo- } \\
\text { HCT }\end{array}$ & $\mathrm{CR}$ & VGPR & $\mathrm{CR}$ & PR & PR & PR \\
\hline $\begin{array}{l}\text { Platelets } \geq 20 \times 10^{-9} / \mathrm{L} \\
\text { reached }\end{array}$ & No & Yes & Yes & Yes & Yes & Yes \\
\hline $\begin{array}{l}\text { Interval platelets } \geq 20 \times \\
10^{-9} / \mathrm{L} \text { reached (in days) }\end{array}$ & NA & 17 & 29 & 26 & 18 & 36 \\
\hline aGVHD & No & No & No & No & No & Yes \\
\hline cGVHD & No & No & Extensive & No & No & No \\
\hline $\begin{array}{l}\text { Transfusion independent } \\
\text { post allo }\end{array}$ & No & Yes & Yes & No & No & Yes \\
\hline $\begin{array}{l}\text { Erythropoietin use } \\
\text { post allo }\end{array}$ & No & Yes & No & No & No & Yes \\
\hline $\begin{array}{l}\text { Anti-myeloma drug } \\
\text { post allo }\end{array}$ & No & No & No & No & Yes & No \\
\hline Relapse status & No & No & No & No & Relapse & No \\
\hline $\begin{array}{l}\text { Interval from allo to first } \\
\text { relapse (in months) }\end{array}$ & NA & NA & NA & NA & 31.51 & NA \\
\hline Survival (in months) & 4.04 & 3.02 & 170.91 & 3.81 & 126.52 & 4.70 \\
\hline Main cause of death & Infection & $\begin{array}{l}\text { TRM: decompensated } \\
\text { right heart failure }\end{array}$ & Alive & Infection & $\begin{array}{l}\text { Relapse/ } \\
\text { progression }\end{array}$ & Infection \\
\hline
\end{tabular}

$M$ male, $F$ female, $I S$ identical sibling, $M U D$ matched unrelated donor, $I g$ immunoglobulin, ISS International Staging System, $C s A$ ciclosporin A, $M M F$ mycophenolate mofetil, $C R$ complete remission, $P R$ partial remission, $V G P R$ very good partial remission, $T R M$ transplant related mortality, $P F S$ progression free survival.

was not associated with conditioning regimen intensity. Five of the six patients had suboptimal responses prealloHCT and three upgraded their responses to $\geq \mathrm{PR}$. Three of the patients became transfusion-independent with two continuing to require erythropoietin. Four patients died within 6 months and one patient at 126 months. Infections were the most common cause of death. Four patients in remission post-allo died due to infections or HCT related complications. Relapse was only observed in one patient who received four further lines of anti-myeloma treatment post-transplant and subsequently died of disease progression at 126 months. This patient's response pre and post allo were stable disease and PR, respectively. The longest survivor is still alive at $170+$ months while on RRT without relapse but extensive cGvHD. This patient, the youngest in our cohort, had high-risk cytogenetics with $t$ $(14 ; 16)$ and $13 q$ del at diagnosis. These results provide evidence of the anti-myeloma activity of allo-HCT even in patients on RRT. However, the infectious morbidity was significant. 
A strategy to mitigate TRM by reducing the doses of drugs in the conditioning regimen was of no clear benefit and resulted in a shortening of PFS [8]. Conversely, our two patients with myeloablative conditioning died of infections $<5$ months post alloHCT. Nonetheless, two of our six patients survived for 126 and 170 months, respectively, following RIC, evidence that there may be a role for alloHCT in selected young, high-risk patients with ESRD. Even in the current era of potent new proteasome inhibitors and monoclonal antibodies, renal impairment in $\mathrm{MM}$ patients remains a challenge.

In the setting of a related donor allo-HCT, renal transplantation is an option. There are case reports and series of sequential auto-HCT and kidney transplants $[9,10]$. Early relapse of myeloma following kidney transplantation, and infectious morbidities are the main obstacles to this approach [11]. Furthermore, loss of kidney graft function has been observed following relapse of myeloma. Patients lacking high-risk features or evidence of residual myeloma prior to kidney transplantation are the best candidates for such living donor renal allografts. There are reports of successful combined allo-HCT and living donor kidney transplants including a recent series of six patients diagnosed with hematological malignancies, five of whom were conditioned with fludarabine, cyclophosphamide, and totalbody irradiation, who underwent combined HCT/kidney transplantation from haploidentical donors [12]. One patient experienced a myeloma relapse at 30 months after allo-HCT and died at 4 years. Overall, four of six patients remain alive, without disease relapse and with long-term renal rejection-free survival. Such combined approaches carry the potential for allo-immune tolerance and avoid the need for continuous immunosuppression and the associated toxicities. In our case series, there were no such combined alloHCT and kidney transplants. However, this data may provide further guidance to clinicians considering allo-HCT in this rare patient population.

\section{Compliance with ethical standards}

Conflict of interest The authors declare that they have no conflict of interest.
Publisher's note Springer Nature remains neutral with regard to jurisdictional claims in published maps and institutional affiliations.

\section{References}

1. Haynes R, Leung N, Kyle R, Winearls CG. Myeloma kidney: improving clinical outcomes?. Adv Chronic Kidney Dis. 2012;19:342-51. https://doi.org/10.1053/j.ackd.2012.03.001.

2. Heher EC, Rennke HG, Laubach JP, Richardson PG. Kidney disease and multiple myeloma. Clin J Am Soc Nephrol. 2013;8:2007-17.

3. Decourt A, Gondouin B, Delaroziere JC, Brunet P, Sallee M, Burtey $\mathrm{S}$, et al. Trends in survival and renal recovery in patients with multiple myeloma or light-chain amyloidosis on chronic dialysis. Clin J Am Soc Nephrol. 2016;11:431-41.

4. Passweg JR, Baldomero H, Chabannon C, Basak GW, Corbacioglu S, Duarte R, et al. The EBMT activity survey on hematopoietic-cell transplantation and cellular therapy 2018: CAR-T's come into focus. Bone Marrow Transplant. 2020. https://doi.org/10.1038/s41409-020-0826-4.

5. Gay F, Engelhardt M, Terpos E, Wasch R, Giaccone L, Auner HW, et al. From transplant to novel cellular therapies in multiple myeloma: European Myeloma Network guidelines and future perspectives. Haematologica. 2018;103:197-211.

6. Bodge MN, Reddy S, Thompson MS, Savani BN. Preparative regimen dosing for hematopoietic stem cell transplantation in patients with chronic kidney disease: analysis of the literature and recommendations. Biol Blood Marrow Transplant. 2014;20:908-19.

7. Van Besien K, Schouten V, Parsad S, Smith S, Odenike O, Artz AS. Allogeneic stem cell transplant in renal failure: engraftment and prolonged survival, but high incidence of neurologic toxicity. Leuk Lymphoma. 2012;53:158-9.

8. Shadman M, Hingorani S, Lanum SA, Pagel JM, Storb R, Maloney DG, et al. Allogeneic hematopoietic cell transplant for patients with end stage renal disease requiring dialysis-a single institution experience. Leuk Lymphoma. 2017;58:740-2.

9. Van den bosch I, Sprangers B, Gertz M. Multiple myeloma and kidney transplantation: the beginning of a new era. Clin Kidney J. 2019;12:213-5.

10. Huskey JL, Heilman RL, Khamash H, Fonseca R. Kidney transplant in the era of modern therapy for multiple myeloma. Transplantation. 2018;102:1994-2001.

11. Shah S, Ibrahim M, Delaney M, Schey S, Bygrave C, Streetly M, et al. Risk of relapse of multiple myeloma following kidney transplantation: a case series report. Clin Kidney J. 2019;12:216-23.

12. Chen Y-B, Elias N, Heher E, McCune JS, Collier K, Li S, et al. Haploidentical hematopoietic cell and kidney transplantation for hematological malignancies and end-stage renal failure. Blood. 2019;134:211-5. 